\title{
The Politics of Reproduction: Race, Medicine and Fertility in the Age of Abolition
}

Review Number: 2214

Publish date: Thursday, 5 April, 2018

Author: Katherine Paugh

ISBN: 9780198789789

Date of Publication: 2017

Price: $£ 65.00$

Pages: 288pp.

Publisher: Oxford University Press

Publisher url: https://global.oup.com/academic/product/the-politics-of-reproduction-9780198789789?cc=gb\&lang= Place of Publication: Oxford

Reviewer: Trevor Burnard

The greatest indictment of the hard-driving slave system in the 18th-century British Caribbean was that the enslaved population never achieved natural population increase (except briefly in Barbados but only by 1810). Abolitionists seized on the failure of slave populations to thrive as a sign that slavery was immoral. Thomas Fowell Buxton in 1832 called the decrease in slave populations in most slave colonies in the British Caribbean 'the best of all tests of the condition of the Negro'. Even slave-owners accepted Buxton's logic, though not his assumption that a declining slave population showed that slavery should be abolished. In 1786 a group of Barbadian planters argued that if negroes are fed plentifully, worked moderately, and treated kindly, they will increase in most places; they will decrease in no place, so much as to require any considerable expense to repair the loss, in number or in value'. It seems common-sense that the managers of slaves should treat slaves well in order that these very valuable assets could work longer and that they could augment the slave population, and the owner's pockets, through 'breeding'. The Jamaican slave owner, Simon Taylor, believed that slaves, just like machines, could wear out from ill-usage and needed to be looked after well: 'they are not steel or iron and we can see neither gudgeons and capooses [small but vital parts of steel mills prone to break when stressed] last in this country'. Yet not all managers of slaves agreed with Taylor. Much to Taylor's chagrin, his overseer, John Kelly, cared nothing about slave welfare but everything about the size of the sugar crop which provided him with his bonus, He worked slaves, including pregnant women, so hard that 'their hearts are broke'. If he continued his practice of killing slaves with overwork so they 'are harassed to Death', Jamaica would be 'a land without Negroes'. Yet Kelly's techniques worked. In 1775, he produced 'the most extraordinary crop that was ever made on any one estate in Jamaica'.(1)

Taylor thought Kelly's strategies foolish and dangerous. He believed that slave reproduction needed to be encouraged, not because he cared much about enslaved peoples' welfare but because otherwise the profits of sugar planting would be eaten up in having to replace dead slaves with new purchases from the Atlantic slave trade. Taylor knew that in North America, slave populations, first in Virginia from the 1720s and in South Carolina from the 1750s, had begun to enjoy natural increase, meaning that North American planters no longer needed to rely upon the slave trade to get labour. Indeed, as Katherine Paugh points out in her relatively short but generally insightful set of essays on the politics of reproduction in British America 
before and after the American Revolution, by the 1770s later revolutionaries like Thomas Jefferson and Benjamin Franklin were worrying about another problem - that African-Americans were reproducing so fast that they were becoming a 'blot upon the country' (p. 26). As Paugh rightly notes, the demographic differences between the plantation colonies of British North America, where slave populations were growing, and plantation colonies in the British Caribbean, where slave populations were declining, helps to explain the differing responses of planters in British America to the prospect of rebellion in 1776. West Indian planters relied too much on the slave trade for rebellion to be an attractive prospect. When the slave trade briefly declined during the American Revolution, especially in the difficult years between 1780 and 1782 when the British West Indies was buffeted by hurricanes and beset by fears of French and Spanish invasion, the plantation economy faltered as planters could no longer replace dead labourers with new ones from Africa.

The problem of slave reproduction in the British Caribbean during the age of abolition and revolution and the advantages the United States of America gained from having a rapidly increasing native-born slave population are perennial issues within slavery studies and have attracted lots of attention from many authors. It is always good, however, to have a well-trodden subject given a new look. Paugh's book is a valuable addition to a venerable literature. In her introduction, Paugh makes some very bold claims about the importance of her work - asserting, for example, that her study 'promises to reshape our understanding of the historical significance of abolitionism, capitalism, slavery and reproduction'. She tends to overstate the importance of her topic, especially in the introduction, where the prose gets overwrought. Her topic is the politics of slave reproduction, mainly in the British Caribbean during the period where planters, politicians and abolitionists believed slavery could be ameliorated rather than ended in ways that would allow the plantation economy to survive. Thus, she promises but does not deliver an analysis based on Karl Marx's use of Thomas Malthus to show that 'abolitionism was an attempt to harness and to commodify the tangible, material, productive powers of Afro-Caribbean women's bodies to the tasks of capital' (p. 16). Proving this would be a major challenge to existing interpretations of abolitionism but readers wanting such a challenge will be disappointed as few of the bold claims about the importance of the politics of reproduction are explored in the book.

I wish the author showed more circumspection in some of her stronger claims, such as her claim that 'AfroCaribbean women's fertility was at the crux of plans for ensuring the economic health of the British Empire during the age of abolition' (p. 189). By the early 19th century, the British Empire encompassed much more than just the West Indies and while what happened in the West Indies was important, its importance was less than it had been. This was a period when Britain expanded its rule into India, Africa and Australia and traded extensively with the United States and with Latin America. That the West Indies had declined in the political economy of empire was one of Eric Williams' major points in his famous linking of the industrial revolution with West Indian slavery. Unlike Paugh, who seems to think that abolitionists and West Indian slave owners were committed together to an ideology of free trade 'that sought to define sexual behavior in the interests of capital,' Williams saw planters abandoned in the 1840s by a British state no longer concerned about the protection of sugar duties and under the thrall of an industrial capitalist bourgeoisie gathered under the banner of free trade. Keith McClelland (not in Paugh's bibliography) shows that West Indian slave owners fought a determined rear guard defence for the maintenance of sugar duties and to an extent were able to thwart abolitionist free traders with the importation of indentured servants from Asia. As Richard Huzzey (also not cited here) shows in his comprehensive study of anti-slavery and empire after 1834, debates over sugar and emancipation were very divisive, making it hard to claim, as Paugh does, that there was unity within a British political class who wanted to 'mold the reproduction of the plantation labor force to the needs of the emerging global, capitalist economy'.(2)

Paugh's book is more modest than she claims in her introduction. It is less a unified text but six individual essays (three of which largely repeat articles published elsewhere) on aspects of the politics of reproduction. Essays on the political economy and the politics of medical knowledge of the politics of reproduction alternate with essays on the remarkable elite free coloured slave family of Mary Hylas, her daughter, Doll, and her grandchildren from the well-documented Newton estate in Barbados. These essays are especially 
good, even if much of the information provided is similar to that in Karl Watson's biography of the family published in 2000.(3) Paugh shows in an analysis of a little studied but important law case that was a precursor to the more famous Somerset case of 1772 that debates over marriages between enslaved people raised issues in Britain about whether being a slave made it impossible to also be a married woman. Paugh uses the case to develop in later chapters the ambivalent position of elite free women of colour and explicates very well the local power politics that Afro-Barbadian women had to navigate in order to establish various kinds of sexual relationships, from concubinage to marriage. They did this in circumstances that were much more complicated than imagined by moralistic abolitionists wedded to ideas of Christian monogamy.

Events on the ground complicated the ideology of reproduction promoted from Britain. The essays on the political economy of reproduction also have much to recommend them. She shows how the gradualist position adopted by planters after 1788 was successful in blunting advocates of the immediate abolition of the Atlantic slave trade. Although this argument is not new - J. R. Ward in his British West Indian Slavery, the most important work on planter amelioration (not cited by Paugh), made a similar argument - there is a wealth of evidence put forward showing how planters adapted their arguments in favour of slavery when facing powerful abolitionist opposition.(4) Planters were adept at using demographic arguments for their own purposes. The chapter which deals with how doctors built on greater interest in using Afro-Caribbean sexuality and fertility to improve enslaved persons' demography in order to increase medical knowledge is particularly valuable. Paugh adds to this relatively familiar story by showing how Afro-Caribbean women were vital participants in this developing medical discourse. Paugh might connect this aspect of her work to the more expansive work of Mark Harrison (not mentioned in the bibliography) in which he shows how commercial and imperial expansion in the tropics enabled doctors experienced in West Indian medicine to become experts in tropical medicine, and able to apply techniques learned in the Caribbean to other places, notably India. $\underline{(5)}$

As might be discerned from the comments above, one weakness of a book that is conceived of as a set of narrowly focused essays is that it can lack wider context. Paugh has limited herself in this work to the consequences (her italics) of demographic failure rather than to the more familiar debate on the causes of enslaved women's infertility in the Caribbean. I can understand the need to delimit of the boundaries of one's study but in this case ignoring the causes of infertility is a mistake. Her knowledge of the secondary literature is patchy. As well as the works listed above that do not seem to have been consulted, she misses important articles by Ken Morgan and Michael Tadman which explain that the main reason for enslaved women's low fertility was the harsh demands of working in sugar.(6) This fact is crucially important for Paugh's argument. Paugh concentrates on how planters and abolitionists argued that it was sexual immorality that led to low fertility but says little about the many abolitionist arguments that what had to be changed in the Caribbean was not slave sexual behaviour but work patterns, especially how slave women worked as field labourers on sugar plantations. At bottom, the reason why Caribbean slave populations could never flourish, especially in the newly opened lands of Trinidad and British Guiana, was that planters insisted on growing sugar and relegated, as did John Kelly in Jamaica in the American Revolution, enslaved women's reproductive interests in favour of increased sugar production. Slave populations in British North America experienced natural increase because enslaved Virginians worked in tobacco, not sugar.

That the politics of reproduction in abolitionist discourse were closely connected to arguments about how enslaved people were worked would have been more apparent if Paugh had extended her analysis away from the older slave colonies of Barbados (where almost all her archival evidence comes from) and Jamaica to the new slave colonies of Trinidad, Berbice and Demerara. As Nicholas Draper and Alvin Thompson (not cited by Paugh) argue, the slave frontier had moved to these areas by the early 19th century and with the creation of the slave registration system in Trinidad in 1813, lots of data on slave population came from these areas.

Paugh really should have read more deeply into British West Indian historiography than she has done. Many books and articles that I expected to be cited are not mentioned in the bibliography, such as books and articles by Christer Petley on Jamaica, an article by Amanda Thornton on the medical care of slaves, Robert 
Fogel's Without Consent, Christina Dierksheide's important study of amelioration, and most egregiously Richard Dunn's major comparative study of work and demography in Virginia and Jamaica. Dunn's book was published in late 2014.(7) Paugh seems to have finished her book in that year, despite it being published in April 2017, as there is only one reference to a book published in 2015. It is also disappointing that Paugh pays so little attention to the voluminous work on Caribbean demography by Barry Higman, citing only one article from 1973 and a book from 1984 and thus ignoring his many works bearing on slave demography written in the last 30 years. $\underline{(8)}$

It is unreasonable to expect Paugh to absorb Alison Bashford and Joyce Chaplin's definitive work on Malthus as a colonial theorist, as their book was only published in 2016. Yet readers of Paugh's book, in which Malthus is highlighted as a major contributor to Caribbean demography, making a great effort to 'reconcile the politics of reproduction in Great Britain and the British Caribbean colonies', (p. 163) will find her thesis hard to square with Bashford and Chaplin's argument that Malthus went out of his way to avoid writing about the West Indies, in part, they suggest, because he had West Indian property. Malthus only mentioned the West Indies once, in a footnote that was a last minute final footnote in the 1806 edition of the Essay on Population. It went on, as Paugh notes, for three pages, but Bashford and Chaplin dismiss its importance, saying that it was rushed and that 'its add-on status betrays avoidance as much as afterthought'. Paugh, by contrast, attaches great importance to this footnote, devoting several pages to what she considers Malthus' 'intervention in the abolitionist debates' (p. 168). Readers of Bashford and Chaplin may find it hard to credit Paugh's contention that 'Malthusian demography ... continued to lend credence to the links between Africans, sexual promiscuity, and infertility' (p. 170) given how little attention Malthus personally devoted to slavery in the West Indies.

Of course, others have noticed that Malthus said virtually nothing about New World slavery. Seymour Drescher in The Mighty Experiment argued that Malthus had no interest in slavery as a transatlantic phenomenon, and implies that abolitionists worked around Malthus rather than using him directly. Drescher believes that demographic arguments were always strongly in abolitionists' favour. Paugh's work is an extended, if sideways, engagement with Drescher's work. Paugh mentions Drescher only twice. She does not think much of Drescher's arguments, disagreeing with him that abolitionism emerged very suddenly as a political issue in Britain in the late 1780s and attacking his well-known argument that abolitionism was a form of econocide - an economically irrational humanitarian gesture on the part of abolitionists. Paugh does not accept Roger Anstey and Drescher's arguments that abolitionists were motivated by religious rather than economic motives. She supports a modified Williams' thesis in which slavery helped fuel capital accumulation and industrialisation. Abolitionists provided humanitarians with good feelings about their 'moral capital' while ensuring that the plantation system and the global trade that it spawned were retained. Thus she tends towards the view that abolitionism was a form of applied hypocrisy, thought she does not say this directly. She argues, moreover, that Drescher's arguments about abolitionist contentions over slave demography should make him amend his 'econocide' argument as so many demographic discussions were shaped, she believes, so as to keep the West Indian plantations prosperous. (10)

To my mind, Drescher's arguments still stand and provide a more convincing explanation of why abolitionism, or at least the abolition of the slave trade in 1807, succeeded than do Paugh's counterassertions. Drescher downplays the impact of the American Revolution on planter fortunes, and admittedly in parts overstates his case as it is clear from Selwyn Carrington's work that between 1779 and 1782 the West Indies suffered greatly from commercial blockade and from the diminishment of the slave trade. Paugh, however, relies too much on Carrington and fails to appreciate that the British West Indies rebounded quickly from the economic blip of the early 1780s. Indeed, her reconstruction of net profits from the Newton Estate shows that the plantation boomed after 1785, with profits spiking in 1792 and again in 1798. By then the Atlantic slave trade to the British Caribbean was at its 18th-century peak.

Drescher is right to argue that the abolition of the slave trade occurred when the West Indian was fundamentally healthy. He is also right to say that abolitionism took off from virtually nothing in 1787. Paugh's argument that it probably took British politicians a few years to formulate a way forward after the 
American Revolution seems unfounded and incorrect - not least because British politicians, as opposed to evangelical aboliitonists, were, except for William Pitt, mostly in favour of the expansion of slavery in the Caribbean in the 1780s and 1790s rather than being supporters of abolition. And Drescher's summation that 'antislavery's victories came without encouragement from either transatlantic economics or metropolitan economists' seems to me a good summary - one informed by economics but at bottom a religiously inspired experiment in mass mobilization of a politically conscious public against activities that besmirched Britain's good name. Yet to Drescher's arguments it is useful to add a little bit of Paugh's thesis, especially the notion that Britain's Caribbean colonies were a pivotal place for the emergence of the politics of reproduction. There is a lot more life still in the question of Afro-women's reproductive choices and the consequences of those choices, and this will keep historians interested and arguing for some time.

\section{Notes}

1. B. W. Higman, Plantation Jamaica 1750-1850: Capital and Control in a Colonial Economy (Kingston, Jamaica, 2005), pp. 201, 221-2.Back to (1)

2. Keith McClelland, 'Redefining the West India interest: politics and the legacies of slave-ownership', In Legacies of British Slave-ownership: Colonial Slavery and the Formation of Victorian Britain, ed. Catherine Hall (Cambridge, 2014), pp. 127-62; Richard Huzzey, Freedom Burning: Anti-slavery and Empire in Victorian Britain (Ithaca, NY, and London, 2012). Back to (2)

3. Karl Watson, A Kind of Right to be Idle: Old Doll Matriarch of Newton Plantation (Barbados, 2000). Back to (3)

4. J. R. Ward, British West Indian Slavery, 1750-1834: The Process of Amelioration (Oxford, 1988). Back to (4)

5. Mark Harrison, Medicine in an Age of Commerce and Empire: Britain and Its Tropical Colonies 16601850 (Oxford, 2010). Back to (5)

6. Michael Tadman, 'The Demographic Cost of Sugar: Debates on Slave Societies and Natural Increase in the Americas', American Historical Review 105 (2000), 1534-75; Kenneth Morgan, 'Slave Women and Reproduction in Jamaica, c.1776-1834', History (2006), 231-53.Back to (6)

7. Christer Petley, Slaveholders in Jamaica: Colonial Society and Culture during the Era of Abolition (London, 2009); Amanda Thornton, 'Coerced Care: Thomas Thistlewood's Account of Medical Practice on Enslaved Populations in Colonial Jamaica, 1751-1786'; Slavery \& Abolition, 32 (2011), 535-59; Robert Fogel, Without Consent or Contract: The Rise and Fall of American Slavery (New York, NY, 1989); Christa Dierksheide, Amelioration and Empire: Progress and Slavery in the Plantation Americas (Charlottesville, VA, 2014) and Richard S. Dunn, A Tale of Two Plantations: Slave Life and Labor in Jamaica and Virginia (Cambridge, MA, 2014).Back to (7)

8. For example, B.W. Higman, Montpelier, Jamaica: A Plantation Community in Slavery and Freedom, 1739-1912 (Kingston, Jamaica, 1998). Back to (8)

9. Alison Bashford and Joyce E. Chaplin, The New Worlds of Thomas Robert Malthus: Rereading the Principle of Population (Princeton, NJ, 2016). Back to (9)

10. Seymour Drescher, Econocide; British Slavery in the Era of Abolition (Pittsburgh: PA, 1977); idem, The Mighty Experiment: Free Labor versus Slavery in British Emancipation (New York, NY, 2002); and idem, 'The Shocking Birth of British Abolitionism', Slavery \& Abolition, 33. Back to (10)

Source URL:https://reviews.history.ac.uk/review/2214

\section{Links}

[1] https://reviews.history.ac.uk/item/295019 